\title{
On the origin of dimorphograptids
}

\author{
LI JI-JIN
}

\begin{abstract}
Li Ji-Jin: On the origin of dimorphograptids. Bull. geol. Soc. Denmark, vol. 35, pp. 171-177, Copenhagen, July 1st, 1987. https://doi.org/10.37570/bgsd-1986-35-18

Previous authors usually considered the Diplograptus stage $\rightarrow$ Akidograptus stage $\rightarrow$ Rhaphidograptus stage $\rightarrow$ Dimorphograptus stage to be an evolutionary series. After research on material of dimorphograptids from the Lower Silurian Kaochiapien Formation, southern Anhui in China, and taking into account the results from analyses on dimorphograptids in general, the writer considers that Dimorphograptus of the elongatus group and Bulmanograptus of the confertus group probably evolved from Parakidograptus, while Dimorphograptus of the hubeiensis group and Bulmanograptus of the deminutus group probably evolved from Glyptograptus and Rectograptus respectively. Rhaphidograptus probably evolved from Climacograptus.
\end{abstract}

Li Ji-Jin, Nanjing Institute of Geology and Palaeontology, Academia Sinica, Chi-Ming-Ssu, Nanjing, China. August, 29th, 1985.

The dimorphograptids mentioned here include three genera, namely, Dimorphograptus (with glyptograptid thecae), Bulmanograptus (with rectograptid thecae) and Rhaphidograptus (with climacograptid thecae). Akidograptus and Parakidograptus are not dimorphograptids because in these two genera the first theca $\left(t h_{1}^{2}\right)$ in the second series of the rhabdosome is normal and is neither reduced nor lost ( $\mathrm{Li} \& \mathrm{Ge} 1981)$.

Previous authors (Bulman, 1938; $\mathrm{Mu} \& \mathrm{Li}$, 1960; Chen \& Lin, 1978; etc.) considered the $\mathrm{Di}$ plograptus stage $\rightarrow$ Akidograptus stage (belonging to the diplograptid type) $\rightarrow$ Rhaphidograptus stage $\rightarrow$ Dimorphograptus stage (belonging to the monograptid type) to be an evolutionary series. Moreover, Chen \& Lin (1978) further considered that the dimorphograptids with only one theca in the uniserial part represented the primitive group in different genera of the Dimorphograptidae; they directly evolved from the Akidograptus after the loss of the first theca in the second series. Later, due to the loss of the thecae one by one in the second series of the rhabdosome, and the uniserial part gradually becoming longer, they became the monograptids. Based on the present material, the paper presents a preliminary discussion on the origin of Dimorphograptids.

While making a study on the Lower Silurian Kaochiapien Formation graptolites from southern Anhui in China ( $\mathrm{Li}, 1983)$, the writer discovered that in the dimorphograptids occurring in the vesiculosus Zone, such as Dimorphograptus erectus Elles et Wood, Dimorphograptus maximus Li, Dimorphograptus minor (Li), Dimorphograptus elongatus Lapworth, Bulmanograptus confertus acuminatus Li, Bulmanograptus similis $\mathrm{Li}$, Bulmanograptus ningguoensis $\mathrm{Li}$, the uniserial part of the rhabdosome is composed of 3-19 thecae; whereas in the dimorphograptids occurring in the cyphus and gregarius zones, such as Dimorphograptus brevis Li, Bulmanograptus alternis $\mathrm{Li}$, Bulmanograptus anhuiensis sp. nov., there is only one theca in the uniserial part of the rhabdosome. Similar results can also be obtained from analyses of dimorphograptids material (Elles \& Wood, 1901-1918; Manck, 1923; Münch, 1952; Obut, Sobolevskaya \& Bondarev, 1965; Obut \& Sobolevskaya 1966; Obut, Sobolevskaya \& Nikolaev, 1967; Obut, Sobolevskaya \& Merkureva, 1968; Churkin \& Carter, 1970; Rickards, 1970; Schauer, 1971; Hutt, 1974; Bjerreskov, 1975; Lenz, 1982). It is helpful to list the stratigraphic range and the number of thecae in the uniserial part of the rhabdosome in the species assigned to the three genera (see tables 1-3).

From these 3 tables, it can be seen that amongst the dimorphograptids, the species with more thecae in the uniserial part of the rhabdosome made their appearence earlier stratigraphically, such as $D$. elongatus Lapworth, Bulmanograptus confertus (Lapworth), and Rhaphidograptus extenuatus (Elles \& Wood); whereas 
Table 1. Stratigraphic range of species in Dimorphograptus.

\begin{tabular}{|c|c|c|c|c|c|c|}
\hline Species & 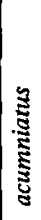 & 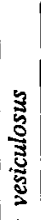 & $\frac{3}{3}$ & 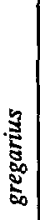 & 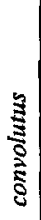 & 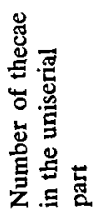 \\
\hline D. elongatus Lapworth & + & + & & & & $10-19$ \\
\hline D. e. flexuosus Schauer & & + & & & & $10-12$ \\
\hline$D$. erectus Elles et Wood & & + & & & & $3-4$ \\
\hline D. hunanensis Wang & & + & & & & 6 \\
\hline D. minor $(\mathrm{Li})$ & & + & & & & 5 \\
\hline D. maximus $\mathbf{L i}$ & & + & & & & 3 \\
\hline D. guanyinqiaoensis Ye & & + & & & & 2 \\
\hline D. urvantzevi Obut et Sob. & & + & + & & & 6 \\
\hline D. procerus Manck & & + & + & & & 5 \\
\hline D. ciliatus Manck & & + & + & & & $3-4$ \\
\hline D. incisus Manck & & + & + & & & 3 \\
\hline $\begin{array}{l}\text { D. erectus nicholsoni } \\
\text { Rickards }\end{array}$ & & + & + & & & $2-3$ \\
\hline D. guichiensis $\mathbf{L i}$ & & + & & & & 1 \\
\hline D. sichuanensis Ye & & + & & & & 1 \\
\hline D. alternis $\mathrm{Li}$ & & & +1. & & & 1 \\
\hline $\begin{array}{l}\text { D. longicaudatus } \\
\text { Chen et Lin }\end{array}$ & & & + & + & & 1 \\
\hline D. brevis $\mathrm{Li}$ & & & + & + & & 1 \\
\hline $\begin{array}{l}\text { D. zintchenkoae } \\
\text { (Obut et Sob.) }\end{array}$ & & & & + & & 1 \\
\hline $\begin{array}{l}\text { D. tenuilongissimus } \\
\text { (Obut et Sob.) }\end{array}$ & & & & + & & 1 \\
\hline $\begin{array}{l}\text { D. longicaudttt s fusiformis } \\
\text { Chen et } \mathrm{Li}_{1}\end{array}$ & & & & & + & 1 \\
\hline D. hubeiensis $\mathrm{Ni}$ & & & & & + & 1 \\
\hline
\end{tabular}

those species with only one theca in the uniserial part of the rhabdosome appeared later, such as Dimorphograptus hubeiensis $\mathrm{Ni}, B$. anhuiensis sp. nov. and Rhaphidograptus sinicus $\mathrm{Mu}$ et al. This
Table 2. Stratigraphic range of species in Bulmanograptus.

\begin{tabular}{|c|c|c|c|c|c|c|}
\hline Zones & 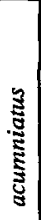 & 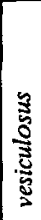 & $\frac{5}{5}$ & 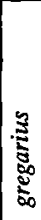 & $\begin{array}{l}3 \\
0 \\
0 \\
0 \\
8 \\
8\end{array}$ & 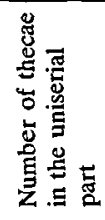 \\
\hline B. confertus (Nicholson) & + & + & + & & & $3-4$ \\
\hline B. c. swanstoni (Lapworth) & + & + & + & & & $4-6$ \\
\hline B. c. acuminatus $\mathrm{Li}$ & & + & & & & 5 \\
\hline B. nankingensis (Sun) & & + & & & & $2-3$ \\
\hline B. similis $\mathrm{Li}$ & & + & & & & 2 \\
\hline B. ningguoensis $\mathrm{Li}$ & & + & & & & 4 \\
\hline $\begin{array}{l}\text { B. decussatus } \\
\text { (Elles et Wood) }\end{array}$ & & + & & & & 2 \\
\hline $\begin{array}{l}\text { B. } d \text {. partiliter } \\
\text { (Elles et Wood) }\end{array}$ & & + & & & & 3 \\
\hline B. longissimus (Kurck) & & + & + & & & $2-3$ \\
\hline $\begin{array}{l}\text { B. epilongissimus } \\
\text { (Rickards) }\end{array}$ & & + & + & & & $3-4$ \\
\hline B. physophora (Nicholson) & & + & + & + & & 1 \\
\hline $\begin{array}{l}\text { B. macilentus aculeus } \\
\text { Chen et Lin }\end{array}$ & & & + & & & 1 \\
\hline B. deminutus $\mathrm{Ni}$ & & & + & & & 1 \\
\hline $\begin{array}{l}\text { B. alaskensis } \\
\text { (Churkin et Carter) }\end{array}$ & & & + & + & & 1 \\
\hline B. macilentus $\mathrm{Mu}$ et al. & & & + & + & & 1 \\
\hline $\begin{array}{l}\text { B. primus } \\
\text { (Obut et Sobolevskaya) }\end{array}$ & & & & + & & 1 \\
\hline B. anhuiensis sp. nov. & & & & + & & 1 \\
\hline $\begin{array}{l}\text { B. spiniferus } \\
\text { (Obot et Sobolevskaya) }\end{array}$ & & & & + & & 1 \\
\hline $\begin{array}{l}\text { B. secundus } \\
\text { (Obut et Sobolevskaya) }\end{array}$ & & & & + & + & 1 \\
\hline
\end{tabular}

evidence demonstrates that the species with more thecae in the uniserial part did not evolved from those species fewer thecae in the uniseral part.

Judging from the type of development at the proximal end, the thecal features and the shape 
Table 3. Stratigraphic range of species in Rhaphidograptus.

\begin{tabular}{|c|c|c|c|c|c|c|}
\hline Zones & & & & & & \\
Species & & & & & & \\
\hline $\begin{array}{c}\text { Rhaphidograptus extenuatus } \\
\text { (Elles et Wood) }\end{array}$ & + & & & & & $2-5$ \\
\hline $\begin{array}{c}\text { Rhaphidograptus sichuanensis } \\
\text { Ye }\end{array}$ & + & & & & & 1 \\
\hline $\begin{array}{c}\text { Rhaphidograptus minutus } \\
\text { Chen et Lin }\end{array}$ & + & + & & & & 1 \\
\hline $\begin{array}{c}\text { Rhaphidograptus toernquisti } \\
\text { (Elles et Wood) }\end{array}$ & + & + & + & + & + & 1 \\
\hline $\begin{array}{c}\text { Rhaphidograptus maslov } \\
\text { Obut et Sobolevskaya }\end{array}$ & & & + & & & 1 \\
\hline $\begin{array}{c}\text { Rhaphidograptus sinicus } \\
\text { Mu et al. }\end{array}$ & & & + & & & 1 \\
\hline
\end{tabular}

of the rhabdosome, the species $D$. brevis occurring in the cyphus Zone of the Lower Silurian Kaochiapien Formation in southern Anhui, is quite similar to Glyptograptus elegans Packham from the lower part of the same zone, or the same horizon; likewise, the species $B$. anhuiensis occurring in the upper part of the gregarius Zone is also quite similar to Rectograptus parakidograptoides $\mathrm{Li}$ from the lower part of the same zone. The writer believes that the above-mentioned $D$. brevis and $B$. anhuiensis probably have evolved from $G$. elegans and $R$. parakidograptoides respectively due to loss of the first theca in the second series of the rhabdosome. (see Fig. 1).

The species D. hubeiensis occurring in the convolutus Zone of the Lower Silurian Lungmachi Formation in Yichang, Hubei $(\mathrm{Ni}, 1978)$ resembles Glyptograptus tamariscus (Nicholson) from the lower part of the same zone; likewise, the species Bulmanograptus deminutus $\mathrm{Ni}$ appearing in the cyphus Zone, resembles Rectograptus bellulus (Törnquist) from the same horizon. Therefore, it seems that the above-mentioned $D$. hubeiensis and $B$. deminutus very probably have evolved from $G$. tamariscus and $R$. bellulus respectively as a result of loss of the first thecae in the second series of the rhabdosome (see Fig. 2).

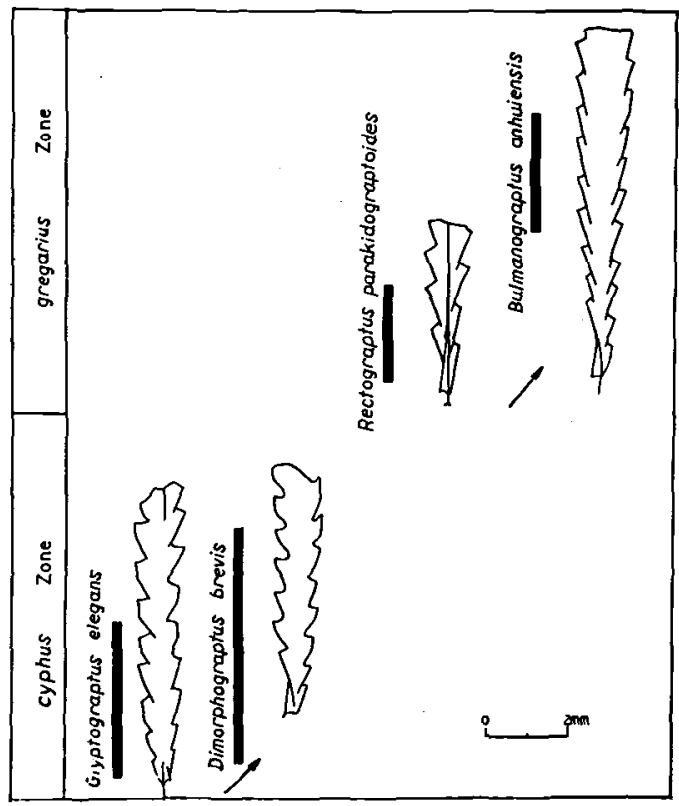

Fig. 1. Evolution of Dimorphograptus and Bulmanograptus in the Lower Silurian of Guichi, Anhui.

At the same time, the species $D$. elongatus Lapworth appearing in the vesiculosus Zone of the Lower Silurian in eastern Thuringen, D. D.

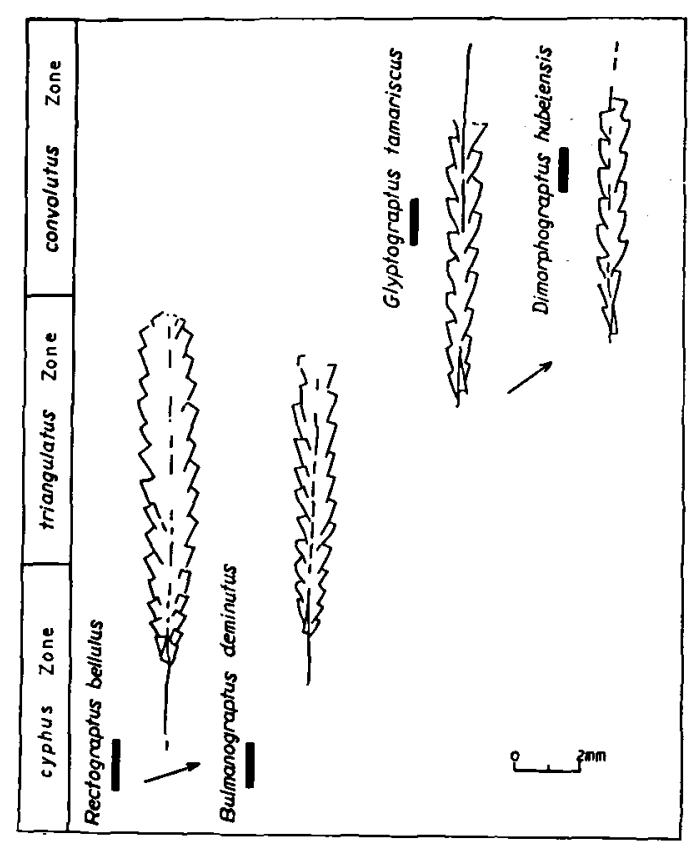

Fig. 2. Evolution of Bulmanograptus and Dimorphograptus in the Lower Silurian of Yichang, Hubei. 


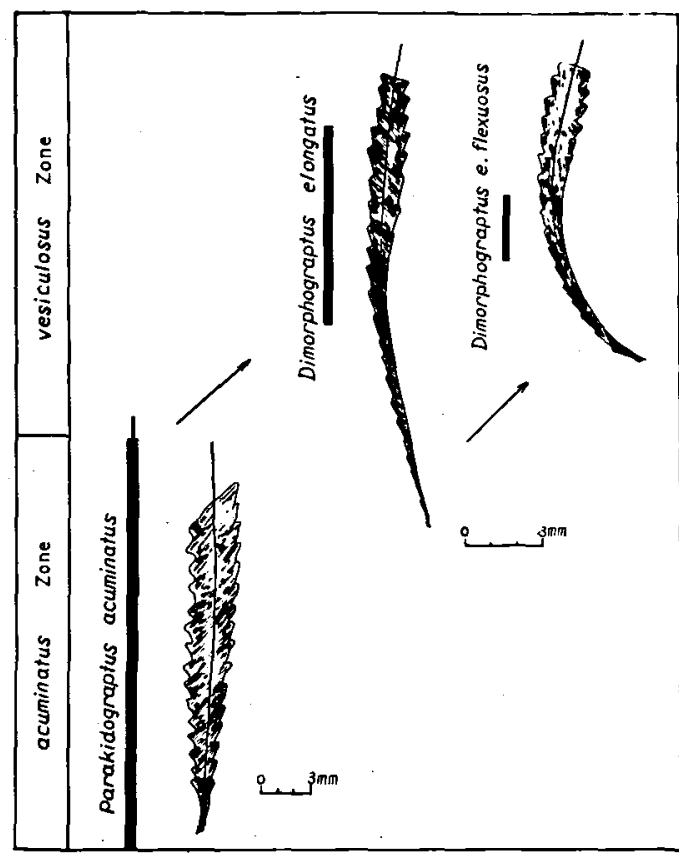

Fig. 3. Evolution of Dimorphograptus in the Lower Silurian of Eastern Thuringen, D.D.R.

R. (Schauer, 1971), is very similar to Parakidograptus acuminatus (Nicholson) appearing in the acuminatus Zone. The former probably has evolved from the latter with loss of most of the thecae in the second series of the rhabdosome. In $D$. elongatus the rhabdosome became further curved dorsally, and might have given rise to Dimorphograptus elongatus flexuosus Schauer (see Fig. 3).

The species Rhaphidograptus toernquisti (Elles $\&$ Wood) ranging from the vesiculosus Zone to the sedgwickii Zone of the Lower Silurian in Britain (Elles \& Wood, 1901-1918; Rickards, 1970) is very similar to, and can be hardly distinguished from Climacograptus rectangularis M'Coy occurring from the acuminatus Zone to the gregarius Zone (Elles \& Wood, 1901-1918). The former very probably has evolved from the latter due to the loss of the first theca $\left(\mathrm{th}_{1}^{2}\right)$ in the second series (See Fig. 4).

In Rickards, Hutt \& Berry (1977)'s consideration, $R$. toernquisti evolved from a slender form of Glyptograptus persculptus Salter. However, the latter occurred at the persculptus Zone and disappeared at its apex of the zone, while the former didn't occur until the vesiculosus Zone came

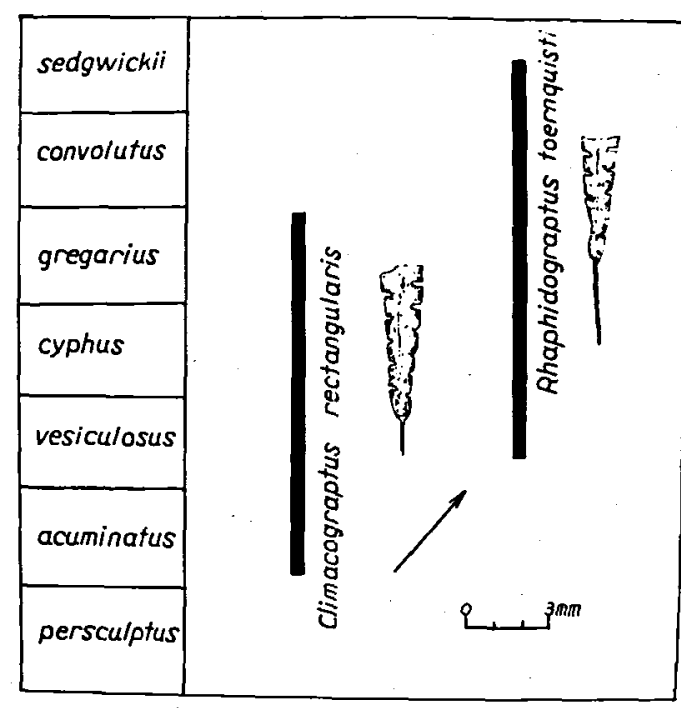

Fig. 4. Evolution of Rhaphidograptus.

into being. Therefore, $G$, persculptus seem by no means to be evolved into $R$. toernquisti.

In species of dimorphograptids with more than two thecae in the uniserial part (exclusive of the Rhaphidograptus), the first theca $\left(\mathrm{th}_{1}^{1}\right)$ in the first series of the rhabdosome are generally sent forth from the sicula at a higher position, and the initial bud begins growing directly upwards, representing a relatively advanced stage in the development of the dimorphograptids (i.e. the monograptid type of development); Parakidograptus is quite near to this type of development because in this genus the first theca $\left(\mathrm{th}_{1}^{1}\right)$ was sent forth from the sicula at a higher position, the initial bud at first grew downwards, but very soon turning upwards. Thus it further evolved to Dimorphograp-

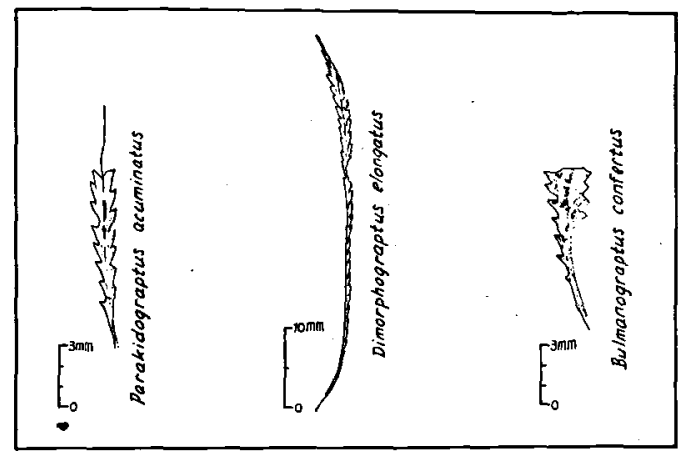

Fig. 5. Comparson of Parakidograptus acuminatus with Dimorphograptus elongatus and Bulmanograptus confertus. 


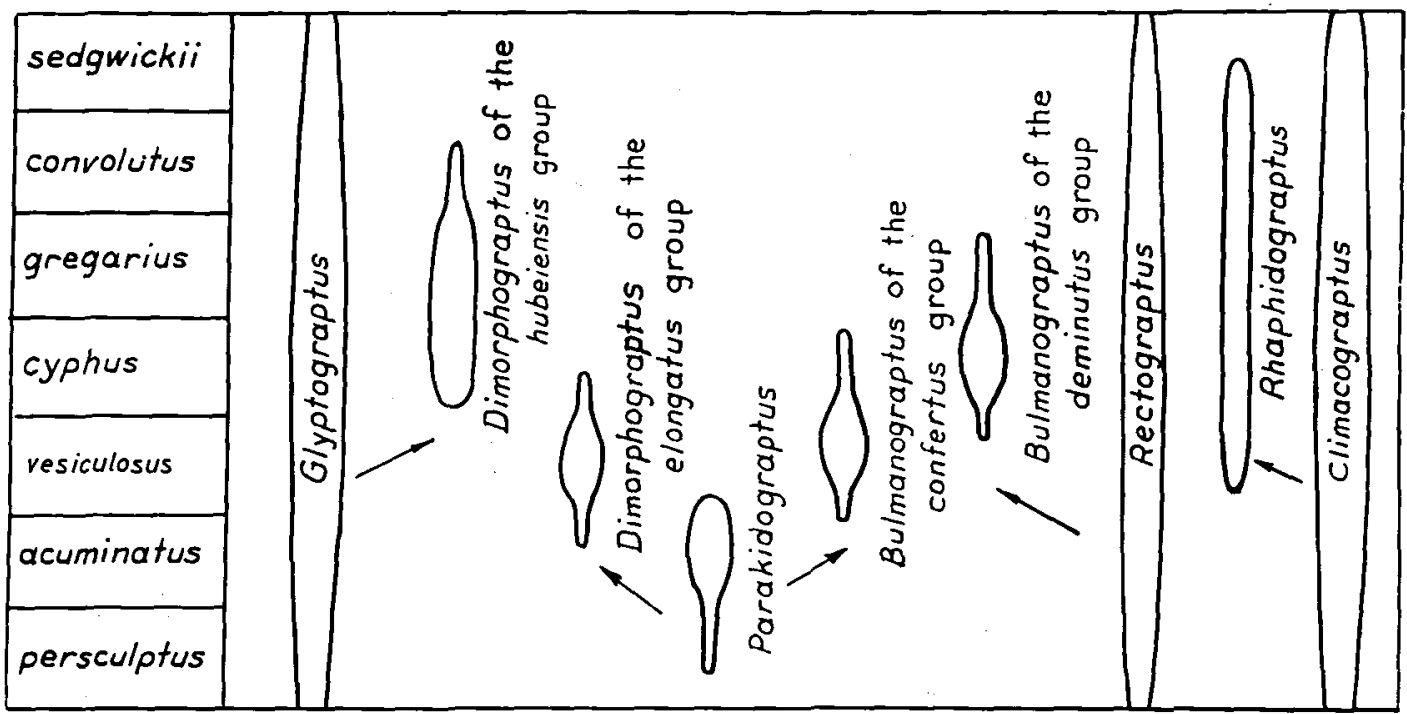

Fig. 6. Showing the probable evolutionary origin of Dimorphograptus, Bulmanograptus and Rhaphidograptus.

tus of the elongatus group and Bulmanograptus of the confertus group (see Fig. 5), whilst in the species with only one theca in the uniserial part of the rhabdosome, the first theca $\left(\mathrm{th}_{1}^{1}\right)$ generally sent forth from the sicula at a lower position, and the initial bud begins to grow first downwards and then upwards, representing a relatively primitive stage in the development of the dimorphograptids (i.e. the diplograptid type of develop-

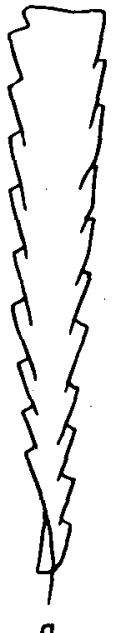

a

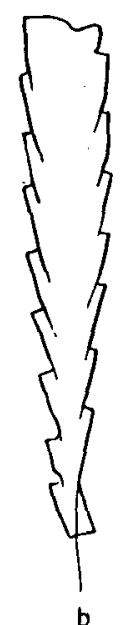

0 $3 \mathrm{~mm}$

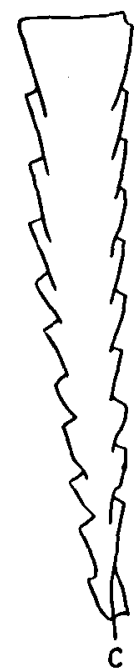

Fig. 7. a-c. Bulmanograptus anhuiensis sp. nov. a. Cat. no. 67285 (Holotype). b-c. Cat. nos. 67286-67287 (Paratype). ment). This reflects their different origins in evolution.

The writer came to the conclusion that Dimorphograptus of the elongatus group and Bulmanograptus of the confertus group probably evolved from Parakidograptus, while Dimorphograptus of the hubeiensis group and Bulmanograptus of the deminutus group probably evolved from Glyptograptus and Rectograptus respectively. Rhaphidograptus probably evolved from Climacograptus. Their evolutionary relationship is shown in Fig. 6.

\section{Description of new species \\ Bulmanograptus anhuiensis sp. nov. \\ (Fig. 7a-c and 8a-c)}

Material: Three well-preserved specimens in low relief.

Description: Rhabdosome small, 7.5-9 mm long with a tapering proximal end, widening gradually to a maximum breath of $1.3-1.4 \mathrm{~mm}$ at the distal end of the rhabdosome. Uniserial part very short and straight, and composed of only one theca, $0.7-1.1 \mathrm{~mm}$ long and $0.4-0.45 \mathrm{~mm}$ wide. Biserial part straight, $6.6-8.3 \mathrm{~mm}$ long and $0.65-0.7 \mathrm{~mm}$ wide at its proximal part and increasing to $1.3-1.4 \mathrm{~mm}$ at the distal end. Sicula short, $0.7-0.9 \mathrm{~mm}$ long and $0.20-0.25 \mathrm{~mm}$ wide across its aperture. Thecae being nearly simple 


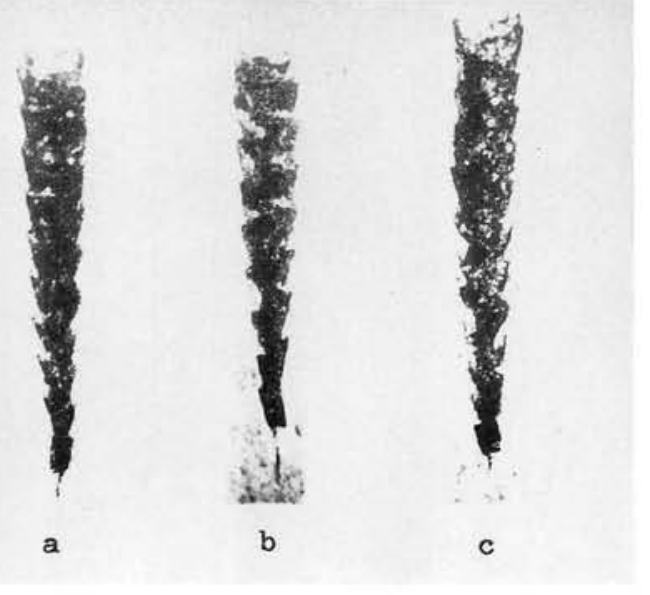

Fig. 8. Bulmanograptus anhuiensis sp. nov. a. Holotype, b-c. Paratypes, enlarged (X6). Cat. nos. 67285-67287.

tubes, $1.5 \mathrm{~mm}$ long and $0.15-0.2 \mathrm{~mm}$ wide across its aperture, alternate in arrangement, apertural margins everted, inclined to axis at a low angle of $10-20^{\circ}$ and overlapping one half the thecal length.

Comparison: In the general features of the rhabdosome, the new species resembles Bulmanograptus macilentus $\mathrm{Mu}$ et al, but in the latter, the rhabdosome is greater in size, the thecae are gently curvature at the distal part of the rhabdosome.

Locality and Horizon: Gregarius Zone of the Kaochiapien Formation, Guichi county, Anhui, China, in association with $D$. brevis $\mathrm{Li}$ and Atavograptus atavus (Jones). Coll. nos. Dh 78-2, 79-1; Cat. nos. 67285 (Holotype), 67286-67287 (Paratype).

Acknowledgements. The writer is very much obliged to Proff. Mu En-zhi and Dr. R. B. Rickards for helpful suggestions regarding the manuscript, to Wen Mei-qin and Zhu Xiao-xin for making the figures, and to Fan Xiao-yi for taking photographs of the figures.

\section{Dansk sammendrag}

Tidligere forfattere har sadvanligvis regnet rakken af former: Diplograptus - Akidograptus - Rhaphidograptus - Dimorphograptus som en evolutionar serie. Som et resultat af studier af graptolitter fra den nedre silure Kaochiapien Formation i det sydlige Anhui i Kina, og efter overvejelser afstedkommet af studier af dimorphograptider kommer forfatteren til den konklusion at Dimorphograptus fra elongatus-gruppen og Bulmanograptus fra confertus-gruppen sandsynligvis udviklede sig fra
Parakidograptus; Dimorphograptus fra hubeiensis-gruppen og Bulmanograptus fra deminutus-gruppen har sandsynligvis udviklet sig fra Glyptograptus og Rectograptus respektive; endelig er Rhaphidograptus nok udviklet fra Climacograptus.

\section{References}

Bjerreskov, M. 1975: Llandoverian and Wenlockian graptolites from Bornholm. Fossils and Strata 8, 94 pp.

Bulman, O. M. B. 1936: Rhaphidograptus, a new graptolire genus. Geol. Mag., 73, 19-26.

Bulman, O. M. B. 1938: Graptolithina. In Schindewolf, O. H. (ed.): Handb. der Palaozool., Band 2D, Lief. 2, 1-92. Borntraeger (Berlin).

Bulman, O. M. B. 1970: Graptolithina. In: Moore, R. C. (ed.): Treatise on Invertebrate Paleontology, 5 (revised). Geol. Soc. Amer. and Univ. Kansas Press XXXII. 163 pp. Kansas.

Chen Xu. \& Lin Yao-kun. 1978: Lower Silurian graptolites from Tongzi, northern Guizhou. Memoirs of Nanjing Institute of Geology and Palaeontology, Academia Sinica, 12. $1-76$.

Churkin, M. Jr. \& Carter, C. 1970: Early Silurian graptolites from southeastern Alaska and their correlation with graptolite sequences in North America and the Arctic. Prof. Pap. U.S. Geol. Surv. 653, 1-51.

Elles, G. L. \& Wood, E. M. R. 1901-1918: A monograph of British graptolites. Pts. 1-XI, Palaeont. Soc. Lond. Monogr., 539 pp.

Hutt, J. E. 1974: The Llandovery graptolites of the English Lake District. Palaeontographical Society, Monog., Pt. 1, $1-56$.

Lenz, A. C. 1982: Llandoverian graptolites of the northern Canadian Cordillera: Petalograptus, Cephalograptus Rhaphidograptus, Dimorphograptus, Retiolitidae and Monograptidae. Life Science Contribution Royal Ontario Museum $130,1-154$.

Li Ji-jin, 1983: Graptolithina. In. Palaeontological Atlas of East China (1). Volume of Early Paleozoic, Chiefly edited by Nanjing Institute of Geology and Mineral Resources. Geological Publishing House, Beijing, China, 493-396. (In Chinese).

$\mathrm{Li} \mathrm{Ji-jin} \mathrm{(in} \mathrm{press):} \mathrm{Lower} \mathrm{Silurian} \mathrm{graptolites} \mathrm{from} \mathrm{southern} \mathrm{An-}$ hui with special reference to the origin of Monograptids.

Li Ji-jin \& Ge Mei-yu, 1981: Development and systematic position of Akidograptids. Acta Palaeontologica Sinica, 20 (3), 225-234.

Manck, E. 1923: Untersilurische Graptolithenarten der Zone 10 des Obersilurs, ferner Diversograptus n. gen. nov. $\mathrm{Na}$ tur, Lpz. 14, 284-289.

Mu En-zhi \& Li Ji-jin, 1960: Graptolite. Science Press (In Chinese).

Münch. A. 1952: De Graptolithen aus dem Anstehenden Gotlandium Deutschlands und der Tschechoslowakei. Geolog. ica, 7. 1-157.

Ni Yu-nan. 1978: Lower Silurian graptolites from Yichang, western Hubei. Acta Palaeontologica Sinica, 17 (4), 387 416 .

Obut. A. M. Sobolevskaya, R. F. \& Bondarev, V. I. 1965: Graptolites of the Silurian of Taymyr. Trudy geol. Inst. Kazan. Filial, 1-120. (In Russian.)

Obut. A. M. \& Sobolevskaya. R. F. 1966: Lover Silurian graptolites in Kazakhstan. Akad. Nauk SSSR, Sibirsk Otdel., Inst. Geol. Geoiz., Minist. Geol. SSSR, Nauchno-issledov. Inst. Geol. Arkiki, 1-56. (In Russian.)

Obut, A. M. Sobolevskaya, R. F. \& Nikoleav. A. A. 1967: Lower Silurian graptolites and stratigraphy of the uplifted margin of the Kolyma Massif (northeastern USSR). Akad. 
Nauk. SSSR, Nauchno-issledov. Inst. Geol. Arktiki, 1-162. (In Russian.)

Obut, A. M., Sobolevskaya, R. F. \& Merkureva, A. P. 1968 Llandovery graptolites from a borehole core in the Norilsk Region. Akad. Nauk SSSR, Otdel. Inst. Geol. Geofiz., Minist. Geol. SSSR, Nauchno-issledov. Inst. Geol. Arktiki, 1-136. (In Russian.)

Rickards, R. B. 1970: The Llandovery (Silurian) graptolites of the Howgill Fells, northern England. Palaeontolographical Society Monograph, 1-108.
Rickards, R. B., Hutt, J. E. \& Berry, W. B. N. 1977: Evolution of Silurian and Devonian graptoloids. Bulletin of the British Museum (Natural History), Geology, 28, 1-120.

Schauer, M. 1971: Biostratigraphie und Taxionomie der Graptolithen der tieferen Silurs unter besonderer Berücksichtigung der tektonischen Deformation. Freiberger Forsch. Hft. C 273, Paläontologie 185 pp. 